\title{
Hydrogeochemical characterization of the urban coastal aquifers of Napoli (southern Italy): an overview
}

\section{Caratterizzazione idrogeochimica degli acquiferi urbani costieri dell'area di Napoli (sud Italia): sintesi preliminare}

\author{
Alfonso Corniello, Daniela Ducci
}

\begin{abstract}
Riassunto: I fenomeni di intrusione marina nelle falde idriche di zone costiere urbanizzate rappresentano un serio problema in relazione al regime di utilizzo della risorsa. Lo studio ha preso in esame l'estesa fascia costiera del Comune di Napoli (Italia meridionale) il cui territorio è compreso tra le aree vulcaniche del Somma-Vesuvio (ad est) e dei Campi Flegrei (ad ovest). In questa fascia costiera sono stati individuati e analizzati tre diversi settori: la piana di Bagnoli-Fuorigrotta $(\mathrm{BF})$, l'area di Monte Echia (E) e la piana ad oriente di Napoli (EN). I dati chimici hanno posto in risalto nei tre settori l'assenza di intrusione marina principalmente per il basso utilizzo delle falde locali. Tuttavia in questi tre settori le caratteristiche chimiche delle acque sotterranee sono risultate assai diverse. Tale diversità è legata, per le prime due aree, al ruolo delle faglie che, anche in relazione al contesto vulcanico generale, favoriscono la risalita di gas profondi (prevalentemente $\mathrm{CO}_{2}$ ). Questi, aumentano la reattività delle acque sotterranee verso le rocce serbatoio determinando, nella zona di Monte Echia, l'origine di acque minerali sulfureo-ferruginose; nella piana di Bagnoli-Fuorigrotta la risalita di gas interagisce invece con l'interfaccia acqua dolce/acque marina causando, nella prima, anche una contaminazione marina non di origine antropica. Infine, nella piana ad oriente di Napoli, la diffusa presenza di lenti di torba, che a luoghi agiscono anche da aquiclude, determina nel sottosuolo ambienti riducenti con acque sotterranee caratterizzate da alte concentrazioni di Fe e Mn.
\end{abstract}

Keywords: coastal aquifers, hydrochemistry, urban groundwater.

Parole chiave: acquiferi costieri, idrogeochimica, idrogeologia urbana.

\section{Daniela DUCCI 莑" \\ Department of Civil, Architectural and Environmental Engineering - University of Naples Federico II, Italy daniela@unina.it}

\section{Alfonso CORNIELLO}

Department of Civil, Architectural and Environmental Engineering University of Naples Federico II, Italy

alfonso.corniello@unina.it

Ricevuto/Received: 21 January 2019-Accettato/Accepted: 08 March 2019 Pubblicato online/Published online: 29 March 2019

This is an open access article under the CC BY-NC-ND license: http://creativecommons.org/licenses/by-nc-nd/4.0/

CC Associazione Acque Sotterranee 2019
Abstract: The presence of phenomena of salt water intrusion in aquifers located in coastal urbanized areas, especially depended on the use of groundwater, is a widespread problem in the world. The study deals with the large coastal belt of the Municipality of Naples(southern Italy), located between the volcanic areas of the Somma-Vesuvius (East) and the Phlegrean Fields (West). Three different coastal sectors were analysed: the plain of Bagnoli-Fuorigrotta (BF), the area of Mount Echia (E) and the area of Eastern Naples (EN). Acquired chemical data allowed of the identification of three different groundwater chemical features and the prevalent absence of sea water contamination, mainly due to the low use of these waters. The study highlighted the chief role of the presence of faults in this volcanic area, favouring the upwelling of gases (prevalently $\mathrm{CO}_{2}$ ). These gases increase the groundwater reactivity causing, in the Mount Echia sector, the presence of sulphurous mineral waters and, in the Bagnoli-Fuorigrotta sector, determining the alteration of the natural relationship between freshwater and saltwater. Moreover, in the Eastern Naples sector, the occurrence of lenses of peat, which play an important bydrogeologic role as aquiclude, can determine reducing condition in the aquifers, with high concentrations in $\mathrm{Fe}$ and $\mathrm{M} n$.

\section{Introduction}

The territory of the city of Napoli, stretched for about $117 \mathrm{~km}^{2}$, is mainly hilly and it consists of tuffs and loose pyroclastics linked to the Phlegrean volcanism. The municipal area intercepts three groundwater bodies (GWBs - 2000/60/ EC, Italian Law: D. Lgs: 152/2006). The volcanic Phlegrean Field GWB (Campi Flegrei - FLE) covers the $67 \%$ of the Municipality, while the Eastern Plain of Naples GWB (Piana ad Oriente di Napoli - P-NAP) the $26 \%$ and the SommaVesuvius GWB (Somma Vesuvio - VES) only a small part (7\%) (Fig. 1).

The coastal strip, with the exception of the tufaceous hills of Posillipo (Figs. 1 and 2) and San Martino (Fig. 3), is formed by plains, more or less wide, in which loose pyroclastics (eroded by the hilly sector), alluvial and / or marine sediments are present and often host the final part of the wider three groundwater bodies. 


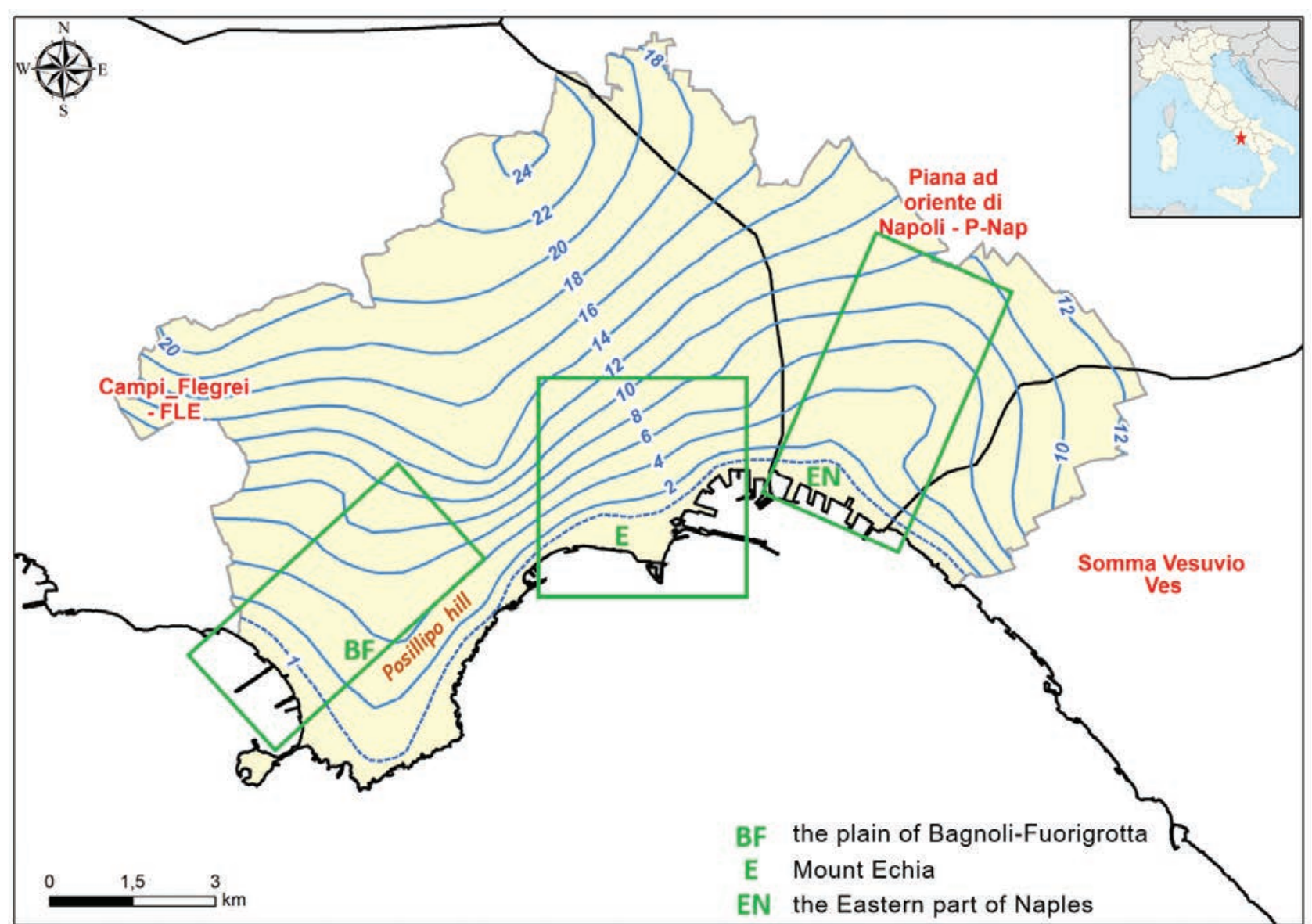

Fig. 1 - The Municipality of Naples (in yellow). In red the three groundwater bodies and in the green squares the three studied coastal areas. In blue, the groundwater levels contour lines ( $m$ a.s.l.) of the year 2003.

Fig. 1 - Il Comune di Napoli (in giallo). In rosso i tre Corpi Idrici sotterranei e nei riquadri verdi le tre aree costiere studiate. In blu i livelli delle acque sotterranee nell'anno 2003 (m s.l.m.).

Unlike what happens in other coastal urbanized areas (Gangopadhyay and Das Gupta 1995; Bocanegra et al. 2010; Custodio 2010; Werner 2010; Di Sipio and Zezza 2011; Thorn 2011; Dentoni et al. 2015), groundwater does not show phenomena of salt water intrusion, above all due to the low use of these waters (Comune di Napoli 1993; Ducci and Sellerino 2015).

The aim of this paper is the preliminary identification and the hydrogeochemical characterization of the urban coastal aquifers of Napoli, highlighting the differences between the three coastal zones.

\section{Hydrogeological Settings of the Study Area}

The investigated area is very complex from the geological point of view. There are many papers describing the geology and the volcanological history of the Neapolitan area. A recent summary is in Carlino (2019). The hydrogeology of the area is detailed in local and specific studies (Celico et al. 2001; Corniello et al. 2000; Ducci and Sellerino 2015; Sellerino et al. 2019).

In the Municipality of Naples, despite the presence of three groundwater bodies, the groundwater flow seems uniform, from $\mathrm{N}$ toward the coast. The differences among the three groundwater bodies are more evident upstream, where FLE and VES, both constituted by volcano-pyroclastic deposits, present a radial groundwater flow (respectively at West and East), while in the P-NAP, prevalently alluvial, the groundwater flow direction is NE-SW, originating at the foot of the carbonate mountains.

The study is focused on three areas (Fig. 1), two plains (Bagnoli-Fuorigrotta BF and Eastern Naples EN) and the final part toward the sea of the hilly part of the city (Mount Echia E).

\section{The plain of Bagnoli-Fuorigrotta}

The plain of Bagnoli-Fuorigrotta falls in the FLE groundwater body and it stretchs for about $4 \mathrm{~km}$ (from SW to NE) in the western sector of the city of Napoli; the tuffaceous Posillipo hill is its southeastern border.

The area falls into the caldera of the eruption of the Neapolitan Yellow Tuff (NYT - 15 ky b.p.; Deino et al. 2004). The Posillipo hill represents the outcropping border of the caldera and at its base the NYT is lowered by faults (Russo et al. 1998 - Fig. 2).

The pyroclastics ejected from the Agnano-Monte Spina eruption (4.1 ky b.p.), in the north-western area of the plain, were reworked in different times in continental or marine environments. 


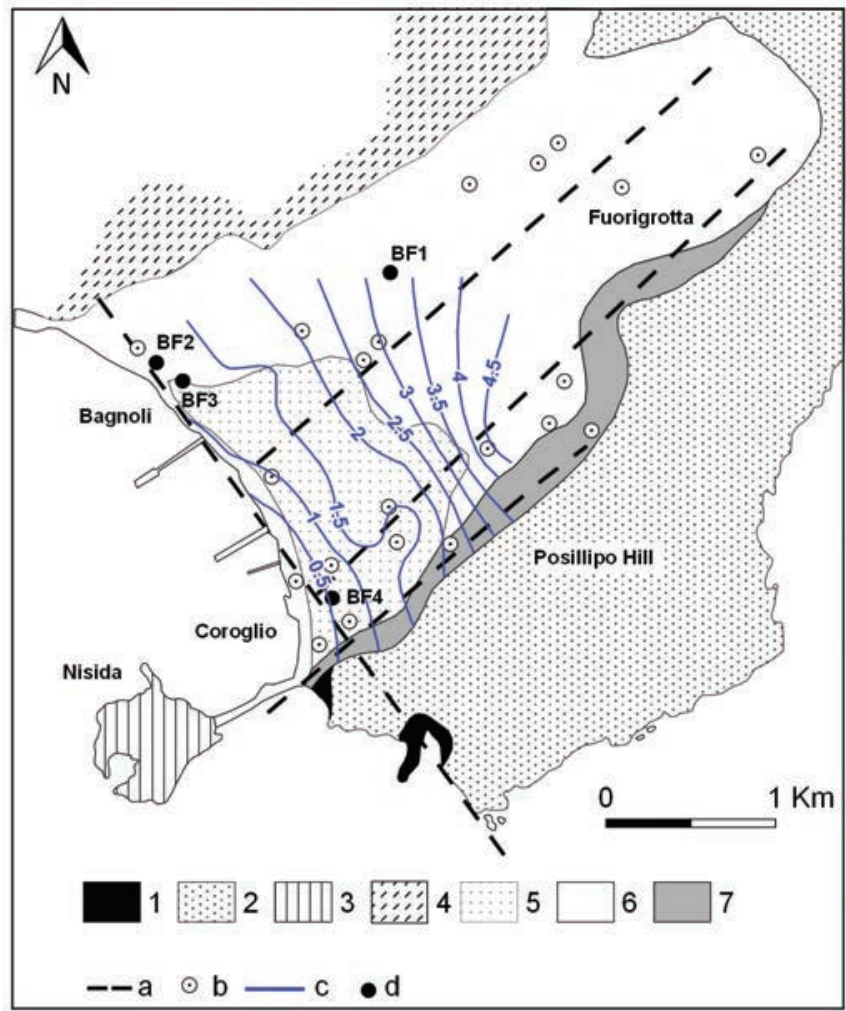

Fig. 2 - Hydrogeological setting of the Bagnoli-Fuorigrotta plain. 1) Coroglio-Trentaremi tuffs; 2) Neapolitan Yellow Tuff: 3) Nisida volcano tuffs; 4) Astroni volcano pyroclastics; 5) marshy deposits and post roman age pyroclastics; 6) pyroclastics and alluvial deposits; 7) loose debris; a) faults; b) drillings; c) groundwater levels contour lines ( $m$ a.s.l., May 2009; from DIGA 2009); d) groundwater sampling points (Tab. 1).

Fig. 2 - Assetto idrogeologico della piana di Bagnoli-Fuorigrotta. 1) Tufi di Coroglio-Trentaremi; 2) Tufo Giallo Napoletano; 3) Tufi del vulcano di Nisida; 4) depositi di palude e piroclastiti di età post-romana; 5) piroclastiti e depositi alluvionali; 6) detriti di versante; a) faglie; b) perforazioni; c) livelli delle acque sotterranee (in m s.l.m.; Maggio 2009; DIGA 2009); d) punti di campionamento delle acque sotterranee (Tab. 1).

In the subsoil are present volcanites and, in the SW part, alluvial and marshy deposits and post-Roman pyroclastics (Fig. 2). The NYT is the bedrock in the eastern and central sector of the plain while, in the western sector, it is absent, probably due to the Agnano-Monte Spina eruption.

Therefore, granulometry varies frequently together with the permeability, and continuous and impervious layers of significant thickness are not present (Corniello and Nicotera 1982; Celico et al. 1991; Comune di Napoli 1993; Autorità di Bacino nord-occidentale della Campania 2004). Groundwater flows within the deposits of greater permeability, from $\mathrm{NE}$ (Fig. 2) (Bagnoli Futura S.p.A. 2002; Celico et al. 2001; DIGA 2009).

The freshwater is overlying saline water and, under undisturbed conditions, the freshwater-saltwater interface reaches, at $600 / 800 \mathrm{~m}$ from the coastline, 60-70 $\mathrm{m}$ below the sea level, according to the Ghyben-Herzberg assumption. That was also verified measuring, in two piezometers, the electrical resistivity variation from the ground level to the depth of 68 m b.g.l. (Bagnoli Futura S.p.A. 2002).

\section{Mount Echia}

Mount Echia (Fig. 3) is a small tufaceous hill that falls in the FLE groundwater body and it stretches, from the sea towards NW, up to the San Martino hill, separating the area where is the Royal Palace of Neaples (Palazzo Reale) from the plain on the west (Riviera di Chiaia - BB' in Fig. 3). At the southern foot of Mount Echia, near the coastline, the sulphurous Spring of Chiatamone S.P.A. (E3 in Fig. 3) was present and it has been closed in 1973, due to water pollution (Corniello et al. 2000).

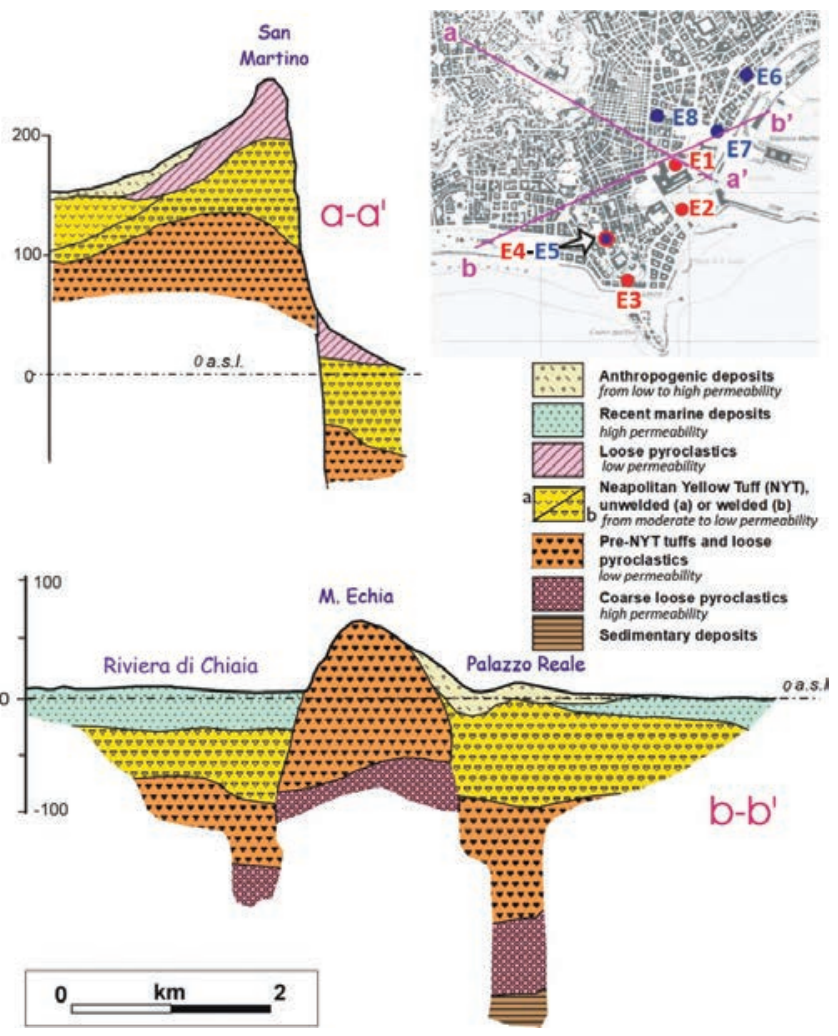

Fig. 3 - The area of Mount Echia. Hydrogeological sections and the map of the area showing the traces of the sections and the groundwater sampling points (blue dots, in red for mineral water; Tab. 1).

Fig. 3 - L'area del Monte Echia. Sezioni idrogeologiche e pianta con le tracce di sezione e i punti di campionamento delle acque sotterranee (punti blu, rossi per le acque minerali; Tab. 1).

Mount Echia consists of pre-NYT tuff which lies on coarse, loose pyroclastics. The same tuff forms the lower part of the San Martino hill (Fig. 3), where, on the top, outcrops the NYT. The contact between basal pyroclastics and tuff is about $80 \mathrm{~m}$ below the sea level at Mount Echia, while, in the plains near Mount Echia, this contact is between 100 and $120 \mathrm{~m}$ below the sea level (Fig. 3). In the plains, above the tuff, there are a few tens of meters of loose marine/pyroclastics deposits.

The geological setting of the area is strongly influenced by tectonic phases that have displaced the same materials to different elevations (Vitale and Isaia 2014).

The detailed stratigraphic data derive from the drilling of a well (E1 in Fig. 3) located in the Royal Palace gardens. The construction of the well, ordered by the King FerdinandoII to increase the availability of drinking water in Napoli, begun 
in 1846 and finished in 1859, reaching the depth of $465 \mathrm{~m}$ (D'Erasmo 1931; Corniello et al. 2000). However, the found groundwater resulted unsuitable for drinking because it was sulphurous, with high TDS and $\mathrm{CO}_{2}$ (Lambertini and Mondelli 1961).

Around Mount Echia, the geological setting determines two overlapping aquifers. The shallow, phreatic, is inside the loose pyroclastics above the tuff (and partly also in the tuff) and represents the final part of the groundwater flow, directed from the hills towards the sea (Fig. 1) (Viparelli 1967; Celico et al. 2001; Autorità di Bacino N-occidentale della Campania 2004). In this aquifer the water table is about 1.7 - $1.8 \mathrm{~m}$ a.s.1., as measured in two wells in the area (Corniello et al. 2000).

The deeper aquifer, located in the coarse loose pyroclastics, is confined by a significant thickness of tuff and its piezometric surface is several meters higher than sea level (Celico et al. 2001).

\section{The eastern part of Naples}

The area is located to the east of the city of Napoli and is the final part, toward the sea, of the larger groundwater body of the Eastern Plain of Naples (P-NAP) (Fig. 1).

The plain is filled (thickness $20-100 \mathrm{~m}$ ) by pyroclastic deposits originating from Vesuvius and the Phlegraean Fields reworked in a coastal, fluvial and marsh environment single multi-layered aquifer with two impermeable units (the welded facies of the Somma-Vesuvius pyroclastic sand the NYT), playing the role of locally confining bed (Ducci and Sellerino 2015). At large scale the aquifer can be considered as a single-layer and unconfined (Fig. 4). In this area the water table is very shallow and the flow is directed toward the sea.

\section{Materials and methods}

The hydrochemical dataset used in this study is composed of 21 sampling points, described in Table 1, considered as more representative of a wider data set (almost 50 groundwater points) coming from previous studies (Lambertini and Esposito 1960; Lambertini and Mondelli 1961; Nota d'Elogio 1979; with the presence of peats. All these sediments constitute a

Comune di Napoli 1993; Corniello et al. 2000; Piscopo et al. 2000; Aiuppa et al. 2003; Autorità di Bacino N-Occidentale della Campania 2004; Adamo et al. 2007; Ducci and Sellerino 2012) and from unpublished studies for the remediation of the areas of Bagnoli (for the steelworks activities carried out from 1910 to 1990) and of the contaminated industrial sites located in the past in the Eastern part of Naples (Comune di Napoli - C.U.G.RI. 2001)

Some groundwater was analyzed by the laboratories of the University of Napoli Federico II, while groundwater samples reported in Adamo et al. (2007) was analysed by the ARPAC (Regional Agency for Environmental Protection of Campania) laboratories.

Temperature, $\mathrm{pH}$, and EC were generally measured on site, using a multi-parameter water quality probe. The error in the ion balance is always less than $5 \%$.

\section{Results and discussion}

The analyses of the three areas have been plotted in the Piper diagram of figure 5. This diagram highlights the differences among the three areas, that fall in different sectors of the diamond, becoming more alkaline from East (Eastern Naples), where they are of magnesium bicarbonate type, to West (Bagnoli - Fuorigrotta plain), where they are of sodium chloride type.

Close to the coastal line of the Bagnoli - Fuorigrotta plain, numerous mineral waters are present, even with high temperatures $\left(\sim 50{ }^{\circ} \mathrm{C}\right.$ ), used in the past as S.P.A.s (Nota d'Elogio 1979; Rasulo 1996) (Tab. 1 and Fig. 2). In the same plain, a groundwater sample taken at a depth of 40 meters (Bagnoli place) had temperatures exceeding $40{ }^{\circ} \mathrm{C}$, a high content of chlorides and was of iron-magnesium type (Di Pastena 2007). Towards the south, still in the coastal area and at the foot of the Posillipo hill, there are a) a spring with high iron content and b) a well in the Cementir plant with water rich in $\mathrm{CO}_{2}$ and with high chloride content (Lambertini and Esposito 1960) (Tab. 1).

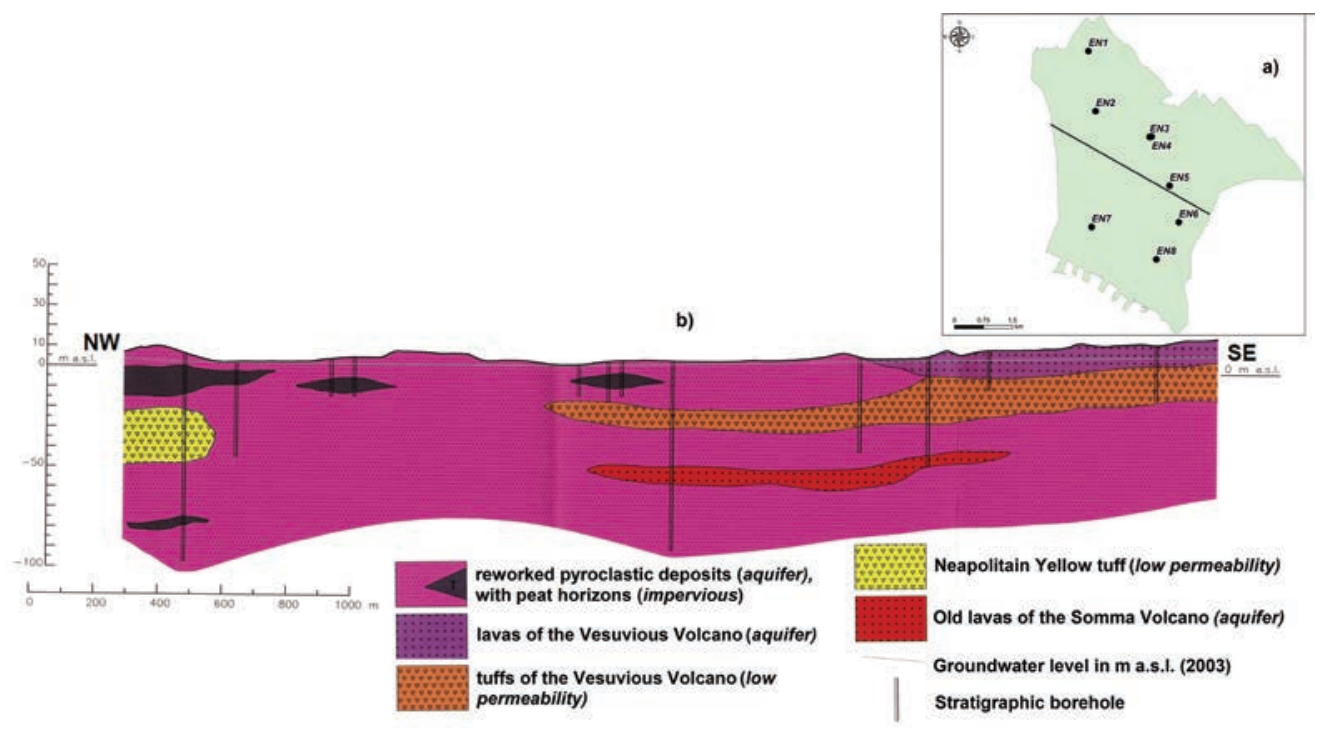

Fig. 4 - The area of Eastern Naples. a) trace of the bydrogeological section (in black) and sampling points (black circles; Tab. 1). b) Hydrogeological section (modified from Comune di Napoli - C.U.G.RI. 2001).

Fig. 4 - L'area di Napoli Est a) traccia della sezione idrogeologica (in nero) e punti di campionamento (cerchi neri; Tab. 1). b) Sezione idrogeologica (modificata da Comune di Napoli - C.U.G.RI. 2001). 


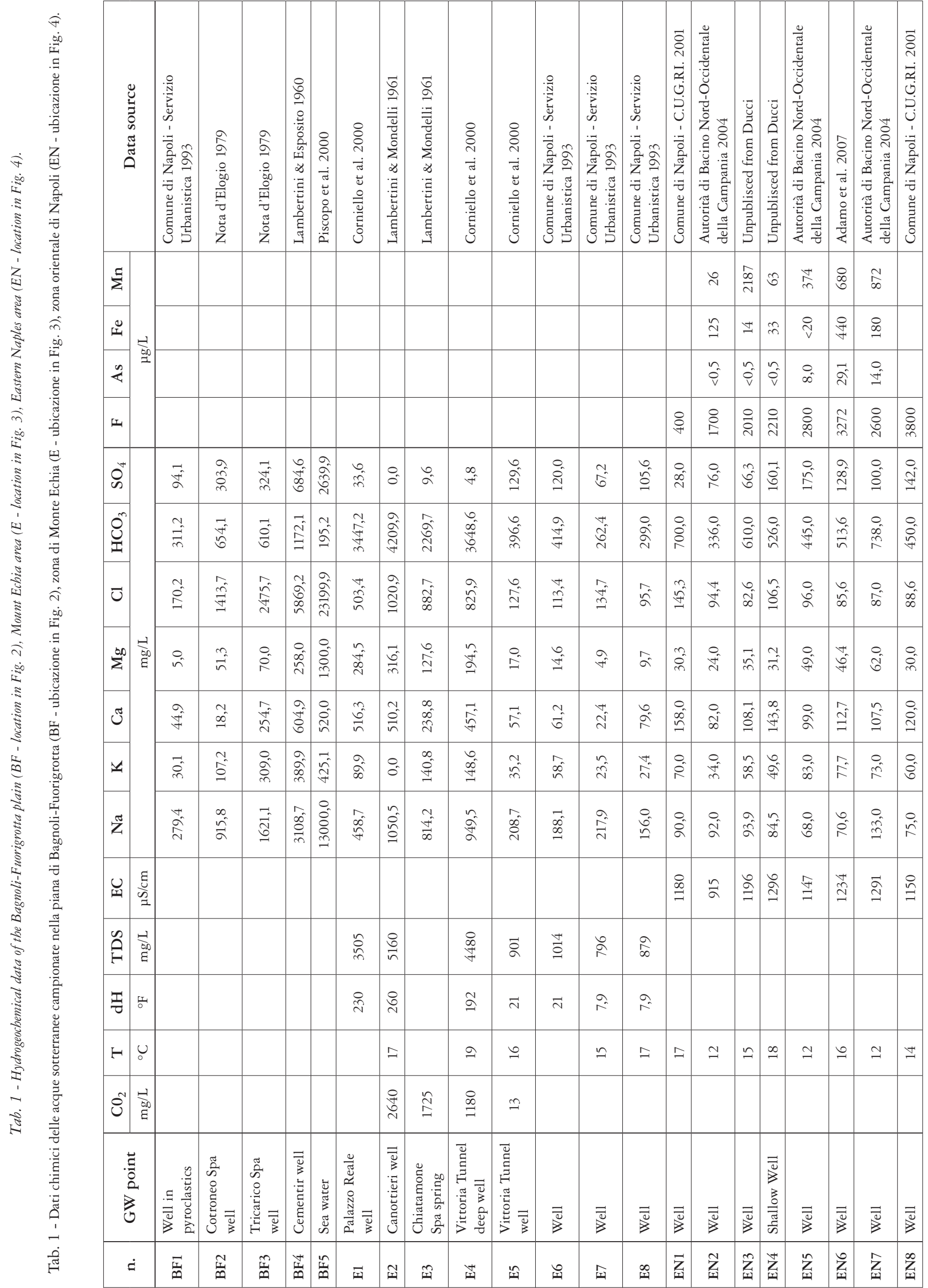




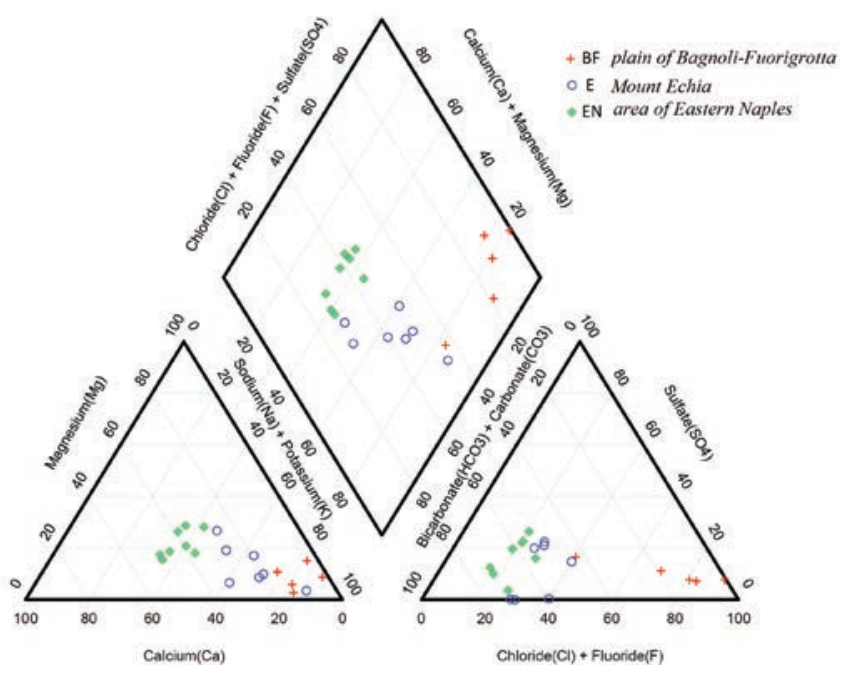

Fig. 5 - PIPER diagram of the groundwater of the three areas.

Fig. 5 - Diagramma di PIPER delle acque sotterranee delle tre aree.

The Schoeller-Berkaloff diagram of figure 6 reveals that the waters of the wells Cotroneo SPA (BF2), Tricarico SPA (BF3) and Cementir (BF4), derive from a typical water of pyroclastics (BF1) affected by seawater intrusion (in different percentages) (BF5). The profiles $\mathrm{BF} 2, \mathrm{BF} 3$ and $\mathrm{BF} 4$ also show the influence of a further factor revealed by the high values of the $\mathrm{HCO}_{3}$ ion, too high to be due to the mixing of the two end members (waters BF1 and BF5). Taking into account the geological context, it is possible a significant upwelling of endogenous $\mathrm{CO}_{2}$ through tectonic discontinuities which have morphological evidences also in the south-western sector of the Posillipo hill (Celico et al. 2001, Bagnoli Futura SpA 2002; Di Pastena 2007; Fig. 2). In this regard, it is significant that the highest temperatures in local groundwater are close the coastline (Fig. 7).

The $\mathrm{CO}_{2}$ upwelling along the faults (parallel or orthogonal to the coast line) increases the $\mathrm{HCO}_{3}$ content in groundwater and also determines the solution of $\mathrm{Fe}$ and $\mathrm{Mn}$ (Fig. 7) in the intercepted aquifers. Moreover, the $\mathrm{CO}_{2}$ and the faults extension modify the natural relationship between freshwater and saltwater, creating a natural sea water intrusion (see

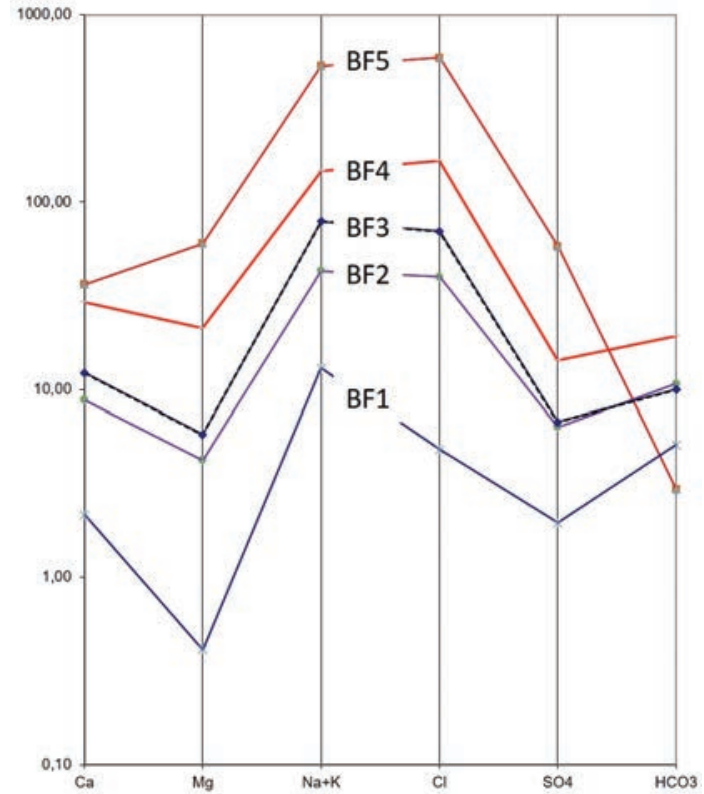

Fig. 6 - Schoeller-Berkaloff diagram of the groundwater of Bagnoli-Fuorigrotta plain (Tab. 1).

Fig. 6 - Diagramma di Schoeller-Berkaloff delle acque sotterranee della piana di Bagnoli-Fuorigrotta (Tab. 1)

$\mathrm{Cl}$ content in figure 7), whose importance is linked to the extent of the upwelling, the use of the groundwater and the proximity of the coastline.

In the Mount Echia area, in the center of Napoli, phreatic groundwater does not show sea water contamination (Comune di Napoli 1993); waters are sodium bicarbonate and with about $890 \mathrm{mg} / \mathrm{L}$ of TDS (Tab. 1; n. E5-E8); the chemical profiles of these waters are shown in the diagram of figure 8 .

The deeper groundwater has been intercepted by three wells (nn. E1, E2, E4 in Tab. 1) and it fed the Spring of Chiatamone (n. E3); these waters do not show seawater contamination but they are very mineralized and with similar chemical characteristics shown by the diagram in figure 8 . These waters have high TDS (some g/L), high $\mathrm{CO}_{2}$ and sometimes $\mathrm{H}_{2} \mathrm{~S}$. Their temperatures are higher than those of the local phreatic groundwater, as well as the content of the main ions with the
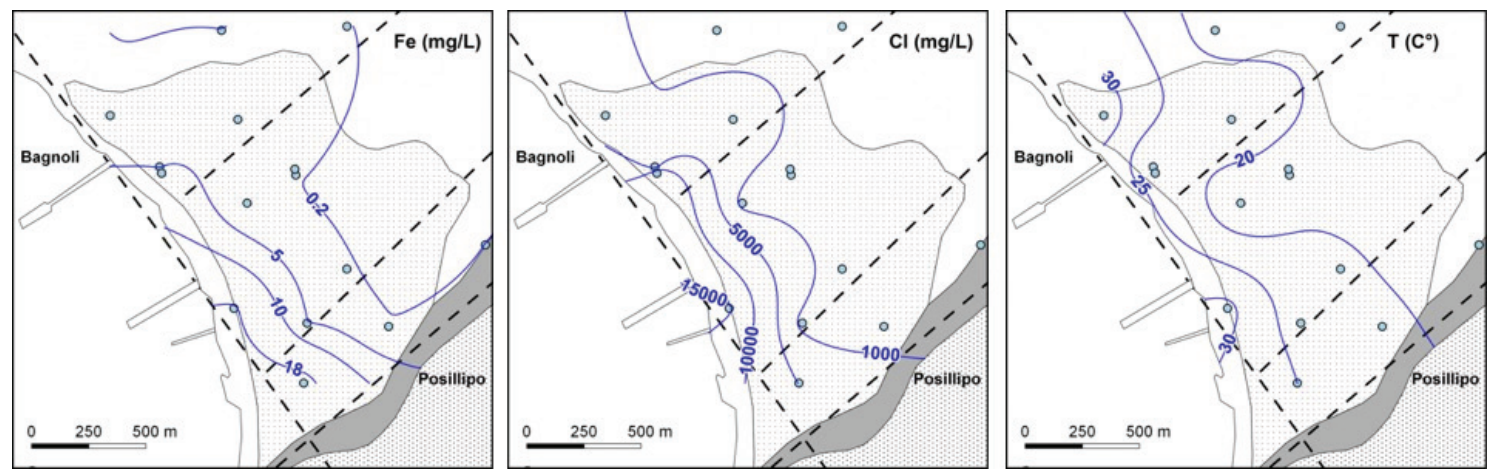

Fig. 7 - Contour lines of $\mathrm{Fe}(\mathrm{mg} / \mathrm{L}), \mathrm{Cl}(\mathrm{mg} / \mathrm{L})$ and $\mathrm{T}\left({ }^{\circ} \mathrm{C}\right)$ in the Bagnoli-Fuorigrotta plain groundwater; for the symbols see Fig. 2 (circles: sampling points); data from Bagnoli Futura 2002.

Fig. 7 - Curve isocone relative a $\mathrm{Fe}(\mathrm{mg} / \mathrm{L}), \mathrm{Cl}(\mathrm{mg} / \mathrm{L})$ e temperatura per le acque sotterranee della piana di Bagnoli-Fuorigrotta; i simboli sono quelli della Fig. 2 (i cerchi indicano i punti di campionamento); dati da Bagnoli Futura 2002. 

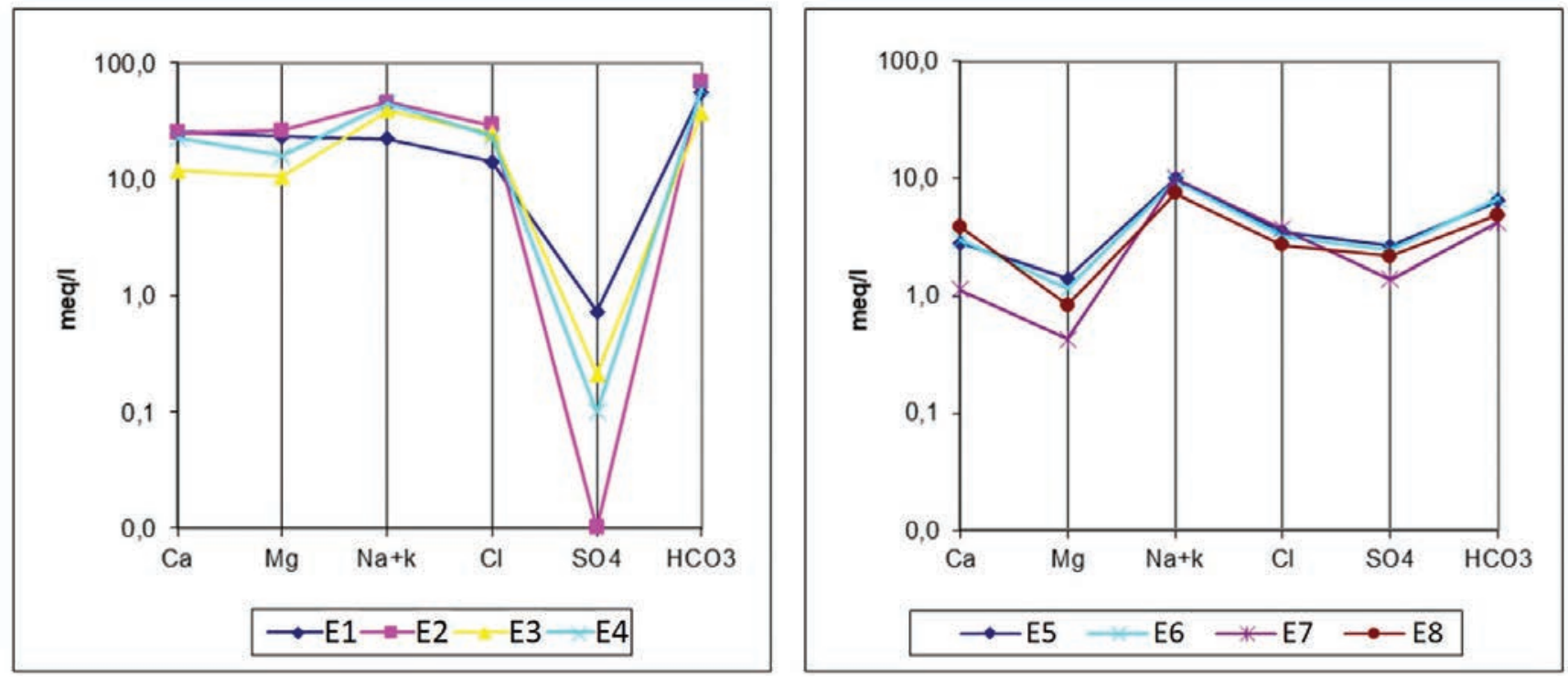

Fig. 8 - Schoeller-Berkaloff diagram of Mount Echia area groundwater (Tab. 1).

Fig. 8 - Diagramma di Schoeller-Berkaloff delle acque sotterranee della zona di Monte Echia (Tab. 1).

exception of sulfates $(<1 \mathrm{meq} / \mathrm{L})$. These characteristics are due to a strong reducing environment (Corniello et al. 2000), also testified by the presence of sand with naphtha (found in the well of Royal Palace at about 340 m b.g.l. - D'Erasmo 1931). The anomalous temperatures, connected to the volcanism of the area and $\mathrm{CO}_{2}$ upwelling along the tectonic discontinuities, favour this environment.

The chemical features of groundwater of the Eastern Naples area (Fig. 5 and Fig. 9) are typical of groundwater flowing in pyroclastic aquifers, with primacy of the alkali ions over Calcium and Magnesium, while the prevalent anion is $\mathrm{HCO}_{3}$. Some groundwater (EN2, EN3, EN6 and EN7 in Fig. 9) are very similar, but with low $\mathrm{SO}_{4}$ content, due to a reducing environment caused by the presence of wide peat lenses, locally confining the aquifer (Fig. $4 \mathrm{~b}$ ). In this environment there is dissolving of $\mathrm{Fe}$ and $\mathrm{Mn}$, that become higher (see Tab. 1). Fluoride is always exceeding the law limit (Directive 98/83/ EC and Italian Legislative Decree 31/2001) of $1500 \mu \mathrm{g} / \mathrm{L}$, due to the natural features of the aquifers constituted by volcanic and pyroclastic rocks. Arsenic exceeding the law limits (EN6 and EN7 in Tab. 1) is due to both, the volcanic origin of the aquifers and the reducing conditions.

\section{Conclusions}

In the coastal part of the city of Napoli, three situations of peculiar hydrogeological interest have been highlighted.

The first is related to the plain of Bagnoli - Fuorigrotta (BF) where a groundwater body, towards the coast, floats on the seawater. The presence of faults in this volcanic area makes possible the upwelling of gases (prevalently $\mathrm{CO}_{2}$ ). These gases and the high temperatures affect the natural relationship between freshwater and saltwater, causing a natural seawater intrusion in groundwater. This modifies the chemical characteristics of groundwater, presenting high salinity, high content in chloride, presence of Fe, etc.

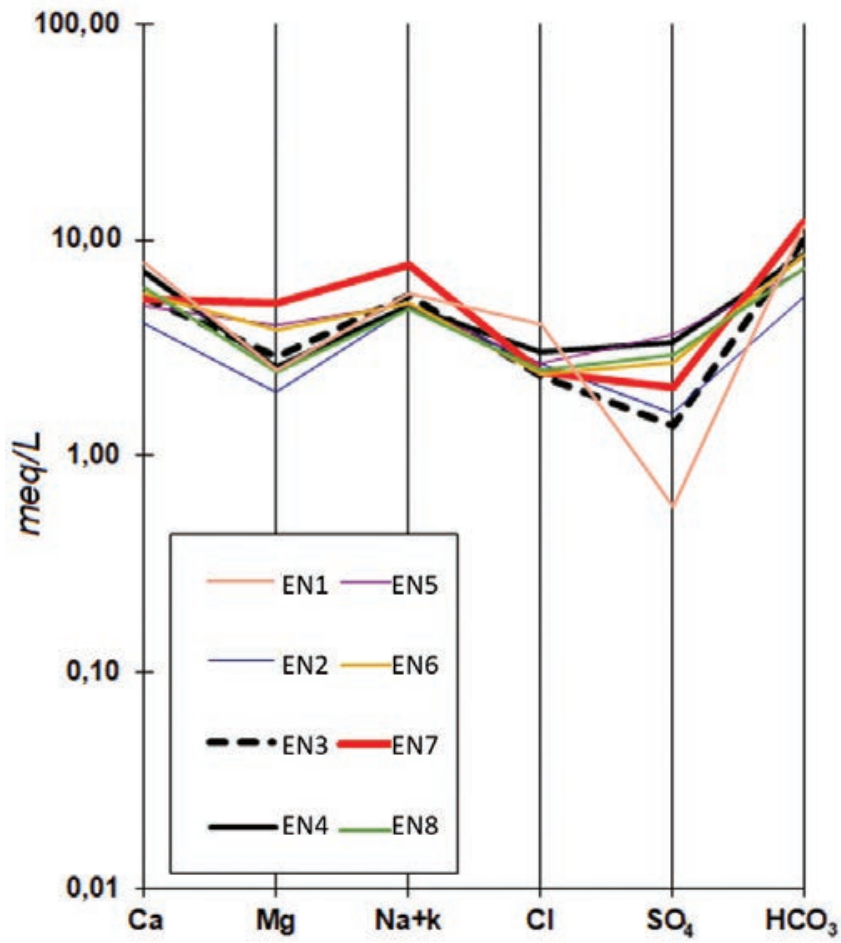

Fig. 9 - Schoeller-Berkaloff diagram of the groundwater of the Eastern Naples area. (Tab. 1).

Fig. 9 - Diagramma di Schoeller-Berkaloff delle acque sotterranee della zona orientale di Napoli (Tab. 1). 
The tuffaceous hill of Mount Echia (E) and the adjacent plains are the other area of interest.

Here the situation is more complex due to the presence of two overlapping aquifers. A shallow groundwater flows in the outcropping and weathered part of the tuff; this aquifer does not present sea water contamination and it is rarely used. The deeper aquifer is in coarse and loose pyroclastics underlying the tuff; the piezometric level in this aquifer is higher than the phreatic level of the shallow aquifer. This deeper aquifer is mineralized (sulphurous, sodium-bicarbonate type and $\mathrm{CO}_{2}$-rich) for the presence of a reducing environment and for the upwelling of endogenous gases $\left(\mathrm{CO}_{2}\right)$. The tuff above the deeper aquifer preserves it from sea water intrusion and reduces the possibility of mixing with the shallow aquifer. Near the sea, at the southern foot of the Mount Echia, the deep waters reach the ground surface throughout some faults, originating the mineral Spring of Chiatamone (E3 in Fig. 3), once very famous but now completely unused. In this regard, the faults that limit Mount Echia, towards South, in activity from the late Pleistocene and Holocene (Amato et al. 2009), are very significant.

The characteristics of the deep aquifer of Mount Echia are peculiar in the hydrochemical panorama of the city of Napoli; in fact, moving away from the Mount Echia area (which is a few $\mathrm{km}^{2}$ wide), mineralized waters are not more present, even in depth.

In the past, the knowledge of these phenomena of mineralized and gas-enriched groundwater has activated municipal projects to enhance this groundwater resource and to identify mineralized flowpaths, also including the old well built in 1846 .

The groundwater chemistry of the Eastern Naples area is marked by the high content of $\mathrm{Fe}$ and $\mathrm{Mn}$, due to the reducing conditions, related to the presence of thick peat levels, especially in the vadose zone, caused by the extensive marshlands present in the past. Moreover, the volcanic nature of the aquifers causes high Fluoride in groundwater and sometimes high Arsenic, this last, lower than in the plain of Bagnoli - Fuorigrotta.

The definition of the peculiar hydrogeological features of the two last areas has produced interesting, useful results. In these groundwater bodies, the Natural Background Levels (NBL for Fe, Mn, As, and F) have been recognized far higher than those indicated by law (Ducci and Sellerino 2012).

\section{REFERENCES}

Adamo N, Imperatrice ML, Mainolfi P, Onorati G, Scala F (eds.) (2007) Acqua - Il monitoraggio in Campania. 2002-2006 "The monitoring in Campania 2002-2006". ARPAC, Napoli, 95-160

Amato L. Guastaferro C, Cinque A, di Donato V, Romano P, Ruello MR, Perriello Zampelli S, Morhange C, Russo Ermolli E, Irollo G, Carsana V, Giampaola D (2009) Ricostruzioni morfoevolutive nel territorio di Napoli. Evoluzione tardo pleistocenica-olocenica e le linee di riva di epoca storica "Morpho evolutive reconstruction in the area of Naples. The late Pleistocene-Holocene evolution and the shorelines in historical time". Méditerranée, 112, 22-31

Aiuppa A, D’Alessandro W, Federico C, Palumbo B, Valenza M (2003) The aquatic geochemistry of arsenic in volcanic groundwaters from southern Italy. Appl Geochem 18, 1283-1296

Autorità di Bacino Nord-Occidentale della Campania (2004) Piano di Tutela delle Acque. Il contributo al Piano di Tutela delle Acque della Regione Campania "The Water Protection Plan. The Campania region contribution to the Water Protection Plan". 3 Vols. SELCA Ed.

Bagnoli Futura S.p.A. (2002) Piano di caratterizzazione Bagnoli - Coroglio. Relazione geologica, idrogeologica e geochimica "The BagnoliCoroglio local Master Plan. Geological, hydrogeological and geochemical report". Unpublished Report

Bocanegra E, Da Silva GC, Custodio E, Manzano M, Montenegro S (2010) State of knowledge of coastal aquifer management in South America. Hydrogeology Journal, 18(1), 261-267

Carlino S (2019) Neapolitan Volcanoes: A Trip Around Vesuvius, Campi Flegrei and Ischia. Geoguide. Springer Nature 2019. 312 pp.doi. org/10.1007/978-3-319-92877-7

Celico F, Esposito L, Mancuso M (2001) Complessità idrodinamica ed idrochimica dell'area urbana di Napoli: scenari interpretativi " $H y$ drodynamical and bydrochemical complexity of the Naples urban area: interpretative scenarios". Geologia Tecnica ed Ambientale 2/2001

Celico P, De Vita P, Nikzad F, Stanzione D, Vallario A (1991) Schema idrogeologico e idrogeochimico dei Campi Flegrei (NA) "Hydrogeological and hydrogeochemical overview of the Phlegrean Fields". Atti I Conv. Naz. Giovani Ricercatori in Geologia Applicata, Univ. Milano, 93, 287-296, Milano

Comune di Napoli - Servizio Urbanistica (1993) Piano regolatore di Napoli: indagini geologiche per l'adeguamento del P.R.G. alla legge regionale 7-1-1983 n. 9 in difesa del territorio dal rischio sismico "The Naples Master Plan: geological investigations for the adaptation of the regional law 7-1-1983 n. 9 for protecting the territory against seismic risk". Unpublished Report

Comune di Napoli - C.U.G.RI. (2001) Studi sull'assetto piezometrico della zona orientale di Napoli "Studies on the piezometric setting in the eastern part of Naples". Unpublished Report, 36 pp.

Corniello A, Ducci D, De Riso R (2000) Le acque minerali della città di Napoli ed il pozzo di Palazzo Reale: aspetti storici, geologici ed idrogeologici "The mineral waters of the Naples city and the well of the Royal Palace : historical and hydrogeological aspects". Proceedings of the Congress“GEOBEN 2000”, EST Stampa Digitale, Torino, 415-422.

Corniello A, Nicotera P (1982) Geologia, Idrogeologia e Idrochimica della zona sud-occidentale dei Campi Flegrei "Geology, bydrogeology and bydrochemistry of the south-western part of the Phlegrean Fields". Memorie e note dell'Istituto di Geologia Applicata, 16, 1-45.

Custodio E (2010) Coastal aquifers of Europe: an overview. Hydrogeology Journal, 18(1), 269-280

Dentoni M, Deidda R, Paniconi C, Qahman K, Lecca G (2015) A simulation/optimization study to assess seawaterintrusion management strategies for the Gaza Strip coastal aquifer (Palestine). Hydrogeology Journal, 23(2), 249-264 
D’Erasmo G (1931) Studio geologico dei pozzi profondi della Campania "Geological study of the deep wells of Campania". Bollettino della Società dei Naturalisti in Napoli, 43, 15-143

Deino A L, Orsi G, de Vita S, Piochi M. (2004) The age of the Neapolitan Yellow Tuff caldera-forming eruption (Campi Flegrei calderaItaly) assessed by $40 \mathrm{Ar} / 39 \mathrm{Ar}$ dating method. Journal of Volcanology and Geothermal Research, 133(1), 157-170

DIGA (2009) Studio idrogeologico ed idraulico a supporto delle attività di progettazione dell'intervento di messa in sicurezza permanente delle acque di falda nell'area di Bagnoli "Hydrogeological and bydraulic study for the remediation of the aquifers in the Bagnoli area". Convenzione tra BagnoliFutura di Trasformazione Urbana S.p.A. ed il DIGA. Unpublished Report

Di Pastena V (2007) Relazione sui fenomeni idrotermali osservati a Bagnoli "Report on the hydrothermal phenomena observed in Bagnoli". Bagnoli Futura S.p.A.. Unpublished Report

Di Sipio E, Zezza F (2011) Present and future challenges of urban systems affected by seawater and its intrusion: the case of Venice, Italy. Hydrogeology Journal, 19(7), 1387-1401

D.Lgs. 31/2001 Attuazione della direttiva 98/83/CE relativa alla qualità delle acque destinate al consumo umano "Transposition of the Council Directive 98/83/EC on the quality of water intended for human consumption". Gazzetta Ufficiale, (52)

D.Lgs. 152/2006 del 03/04/2006 Norme in materia ambientale "Laws in the field of Environment". G. U. n. 88del 14/04/2006-Suppl. Ord. n. 96

Ducci D, Sellerino M (2012) Natural background levels for some ions in groundwater of the Campania region (southern Italy). Environmenta Earth Sciences, 67, 683-693

Ducci D, Sellerino M (2015) Groundwater mass balance in urbanized areas estimated by a groundwater flow model based on a 3D hydrostratigraphical model: the case study of the eastern plain of Naples (Italy). Water Resources Management, 29 (12), 4319-4333

EC (1998) Directive 98/83/EC 3 November 1998 Quality of water intended for human consumption. Off J EurCommun L 330:5-12

EC (2000) Directive 2000/60/EC 23 October 2000 Framework for Community action in the field of water policy. Off $\mathrm{J}$ EurCommun L 327:1-72

Gangopadhyay S, Das Gupta A (1995) Simulation of Salt-Water Encroachment In A Multi-Layer Groundwater System, Bangkok, Thailand. Hydrogeology Journal, 3(4), 74-88
Lambertini D, Mondelli G (1961) Relazione sull'analisi di un'acqua profonda rinvenuta nella zona litoranea, in prossimità del Palazzo Reale di Napoli "Report on the analysis of groundwater sampled in the coastal area, next to the Royal Palace of Naples". Bollettino della Società dei Naturalisti in Napoli, 70, 185-193

Lambertini D, Esposito AM (1960) Acque del sottosuolo dei Campi Flegrei utilizzate a scopo industriale "Phlegrean Fields's groundwater used for industrial scopes". Bollettino della Società dei Naturalisti in Napoli, Vol. LXIX

Nota d'Elogio E (1979) Le acque minerali e termali della Provincia di Napoli "Mineral and thermal waters of the Naples Province". Memorie e note dell'Istituto di Geologia Applicata, 15, 1-108

Piscopo V, Allocca V, Brusa G, Cesario M, Monetti V, Pianese L (2000) Il fronte sorgivo di Castellammare di Stabia (Napoli): variazioni del grado di mineralizzazione delle acque sotterranee quali conseguenza dell'eterogeneità di un acquifero carbonatico "Castellammare di Stabia springs (Naples): variation of groundwater mineralization and heterogeneity of the carbonate coastal aquifer". Bollettino della Societa Geologica Italiana, 119(3), 567-580

Rasulo G (1996) Bagnoli: Una proposta operativa. La risorsa termale dell'area di Bagnoli "Bagnoli: an operative proposal. The thermal resource in the Bagnoli area", Pubblicazione finanziata dalla Camera di Commercio Industria ed Artigianato e Agricoltura di Napoli, 86-93

Russo F, Calderoni G, Lombardo M (1998) Evoluzione geomorfologica della Depressione Bagnoli-Fuorigrotta: periferia urbana della città di Napoli "Geomorphological evolution of the Bagnoli-Fuorigrotta plain: urban periphery of the Napoli town". Bollettino della Societa Geologica Italiana, 117, 21-38

Sellerino M, Forte G, Ducci D (2019) Identification of the natural background levels in the Phlaegrean fields groundwater body (Southern Italy). Journal of Geochemical Exploration, 200: 181-192

Thorn P (2011) Groundwater salinity in Greve, Denmark: determining the source from historical data. Hydrogeology Journal, 19(2), $445-461$

Viparelli C (1967) Le acque sotterranee. In "Il sottosuolo di Napoli" a cura del Comune di Napoli . "Groundwater. In 'The subsoil of Naples' edited by the Municipality of Naples", AGIF, Aversa, 147-164

Vitale S, Isaia R (2014) Fractures and faults in volcanic rocks (Campi Flegrei, southern Italy): insight into volcano-tectonic processes. International Journal of Earth Sciences, 103(3), 801-819

Werner AD (2010) A review of seawater intrusion and its management in Australia. Hydrogeology Journal, 18(1), 281-285 